\title{
ДО ПИТАННЯ ПРОВОКАЦІЇ ЗЛОЧИНУ ПІД ЧАС ПРОВЕДЕННЯ НЕГЛАСНИХ СЛІДЧИХ (РОЗШУКОВИХ) ДІЙ У ПЛОЩИНІ ПРАКТИКИ ЄВРОПЕЙСЬКОГО СУДУ З ПРАВ ЛЮДИНИ
}

Шевченко Ю. А.

\begin{abstract}
Наукова стаття присвячена питанню підбурювання до вчинення злочину з боку службових осіб під час проведення оперативно-розшукової діяльності чи негласних слідчих (розшукових) дій. Зокрема, у роботі аналізується чинне законодавство, яке регулює таку діяльність службових осіб, а також стала практика Європейського суду з прав людини. Як висновок із проведеного дослідження до уваги пропонуються орієнтовні критерії належного здійснення оперативно-розшукової діяльності, а також проведення негласних слідчих (розшукових) дій, в межах яких здійснюється підбурювання до вчинення злочину, а також за якими не будуть наявні порушення прав людини і докази не будуть визнані недопустимими.
\end{abstract}

Ключові слова: провокація злочину, підбурювання, оперативно-розшукова діяльність, службова особа, негласні слідчі (розшукові) дії, Європейський суд з прав людини, стала практика, досудове розслідування, права людини.

Научная статья посвящена вопросу подстрекательства к совершению преступления со стороны должностных лиц в ходе проведения оперативно-розыскной деятельности или негласных следственных (розыскных) действий. А именно в роботе анализируются действующее законодательство, которое регулирует такую деятельность лиц, а также практика Европейского суда по правам человека. Как вывод с проведенного исследования к вниманию предлагаются ориентировочные критерии надлежащего осуществления оперативно-розыскной деятельности, а также проведения негласных следственных (розыскных) действий, в границах которых осуществляется подстрекательство к совершению преступления, а также за которыми будут присутствовать нарушения прав человека и доказательства будут признаны недопустимыми.

Ключевые слова: провокация преступления, подстрекательство, оперативно-розыскная деятельность, должностное лицо, негласные следственные (розыскные) действия, Европейский суд по правам человека, повсеместная практика, досудебное расследование, права человека.

The article is devoted to the question of incitement to commit a crime on the part of officials in the course of operative-search activity carrying out or secret investigative (search) actions. In particular, the work analyzes the existing criminal procedural law, legislation on operational and investigative activities that regulates such activities of officials, as well as the practice of the European Court of Human Rights. During the analysis, considerable attention is paid to the legal positions of the European Court of Human Rights, which should be used as the main benchmark for incitement to commit an offense by officials. Such a requirement is due to the fact that Ukraine is a member of the Council of Europe. Consequently, in accordance with the Constitution of Ukraine, valid international treaties, binding agreement of which provided by Verkhovna Rada of Ukraine, is a part of the national legislation of Ukraine. Since the moment of ratification of Convention for the Protection of Human Rights and Fundamental Freedoms, Ukraine, as well as a number of other legal European countries, has undertaken to adhere to the minimum standards of human rights guaranteed by the Convention in the national legal system. These commitments have been developed in national legislation, which states that the European Convention on Human Rights and Fundamental Freedoms of 1950 and the practice of the European Court of Justice are the source of law in Ukraine, and the national legal system must take into account the precedents elaborated by the European Court of Human Rights. As a conclusion from the study, it is suggested to take into account benchmarks that are systematized on the basis of a number of judgments of the European Court of Human Rights on the proper operative-search activity carrying out, as well as secret investigatory (search) actions, which perform incitement to commit a crime, according to which no human rights violations and evidence will not be recognized inadmissible.

Key words: provocation of crime, incitement, operative-search activity, official, secret investigation (search) action, European Court of Human Rights, to become a practice, pre-trial investigation, human rights.

Постановка проблеми та їі актуальність. Сьогодні питання захисту прав людини на стадії досудового розслідування під час здійснення кримінального провадження уповноваженими службовими особами відповідних органів $\epsilon$ надзвичайно актуальним. Така актуальність зумовлена численними скаргами, з якими особи звертаються до Європейського суду з прав людини (далі - Європейський суд, Суд) за захистом своїх порушених прав. Слід сказати, що переважна більшість скарг у контексті статті 6 Європейської конвенції з прав людини і основоположних свобод (далі - Конвенція, Європейська конвенція), яка стосується кримінальних проваджень, спрямована на те, щоб Суд встановив неправомірне поводження з боку правоохоронних органів щодо скаржника. Не стали виключенням заяви щодо проведення службовими особами підбурення до вчинення злочину заявниками в межах здійснення оперативно-розшукової діяльності чи негласних слідчих (розшукових) дій. Як правило, результати, отримані під час проведення таких дій, лягають в основу доказування вини особи. Проте якщо ці дії були здійснені з порушенням вимог національного законодавства, а також не відповідно до сталої практики Європейського суду, то може постати логічне запитання: а чи $є$ допустимими докази у такому випадку та чи можна такі докази ставити в основу обвинувачення? Не досить чітка нормативно-правова регламентація питання підбурювання до вчинення злочину у національному законодавстві може породжувати такі наслідки, як порушення прав людини, а також визнання доказів, які отримані внаслідок проведення оперативно-розшукової діяльності чи нег- 
ласних слідчих (розшукових) дій, недопустимими. Тож убачається необхідність дослідження цього питання.

Аналіз останніх досліджень і публікацій. Різні аспекти проблеми провокації злочину з боку службових осіб правоохоронних органів під час проведення оперативно-розшукової діяльності чи негласних слідчих (розшукових) дій були предметом дослідження багатьох науковців, серед яких М.В. Багрій, О.А. Білічак, В.В. Вапнярчук, С.О. Гриненко, С.В. Давиденко, В.А. Динту, О.М. Дроздов, В.В. Комашко, С.С. Кудінов, Д.Б. Сергєєва, А.В. Панова, С.С. Тарадойна, В.Г. Уваров, С.Б. Фомін, Р.М. Шехавцов та інші вчені. Проте питання проведення аналізу практики Суду, а також систематизації критеріїв, що були вироблені у різних справах та сформували сталу практику Європейського суду у цій площині, досі залишається нерозглянутим.

Метою статті $\epsilon$ проведення аналізу чинного законодавства, що регулює коло повноважень службових осіб правоохоронних органів під час проведення підбурювання до вчинення злочину в межах оперативно-розшукової діяльності чи негласних слідчих (розшукових) дій, а також аналіз позиції Європейського суду з цього питання. Не менш важливою й основною метою статті $\epsilon$ вироблення орієнтовних критеріїв, які вважається доцільним запровадити у національне законодавство, щодо належного здійснення оперативно-розшукової діяльності, а також проведення негласних слідчих (розшукових) дій, в межах яких здійснюється підбурювання до вчинення злочину, а також за якими не будуть наявні порушення прав людини і докази не будуть визнані недопустимими.

Виклад основного матеріалу. Стаття 246 Кримінального процесуального кодексу України (далі - КПК України) визначає основні умови щодо ініціювання проведення негласних слідчих (розшукових) дій. Зокрема частина 2 статті 246 КПК України передбачає, що підставою проведення негласних слідчих (розшукових) дій $\epsilon$ неможливість отримання відомостей про злочин та особу, яка його вчинила, в інший спосіб. Частина 3 цієї статті презюмує, що можливість чи неможливість отримання відомостей має бути визначена слідчим, детективом, прокурором, слідчим суддею стосовно цієї чи інших подібних негласних слідчих (розшукових) дій. Важливою умовою також $\epsilon$ те, що негласні слідчі (розшукові) дії можна проводити у кримінальному провадженні виключно щодо тяжких чи особливо тяжких злочинів [1].

Вимогам, зазначеним вище, також відповідає зміст Закону України «Про оперативно-розшукову діяльність», а саме частини 1 статті 6, де передбачено, що підставами для проведення оперативно-розшукової діяльності вважаються такі як наявність достатньої інформації, одержаної в установленому законом порядку, що потребує перевірки за допомогою оперативно-розшукових заходів і засобів, про: злочини, що готуються; осіб, які готують вчинення злочину; осіб, які переховуються від органів досудового розслідування, слідчого судді, суду або ухиляються від відбування кримінального покарання; тощо [2].

Проте норми, що регулюють здійснення службовими особами оперативно-розшукової діяльності та проведення негласних слідчих (розшукових) дій, згадані вище, не $\epsilon$ досконалими під час здійснення заходів, що включають провокацію злочину, оскільки може йтися про такі наслідки, як визнання доказів, отриманих під час проведення оперативно-розшукової діяльності або негласних слідчих (розшукових) дій, недопустимими, а також про порушення прав людини.

Відповідно до статті 9 Конституції України чинні міжнародні договори, згода на обов'язковість яких надана Верховною Радою України, $\epsilon$ частиною національного законодавства України [3]. 3 моменту ратифікації Європейської конвенції Україна, як і ряд інших правових європейських держав, узяла на себе зобов'язання дотримуватись мінімальних стандартів прав людини, гарантованих Конвенцією, у національній правовій системі. Ці зобов'язання отримали розвиток у статті 17 Закону України «Про виконання рішень та застосування практики Європейського суду з прав людини», де зазначено, що Європейська конвенція з прав людини і основоположних свобод 1950 року та практика Європейського суду $\epsilon$ джерелом права в Україні, і національна правова система повинна враховувати прецеденти, вироблені Європейським судом з прав людини [4].

Так, до прикладу можна привести рішення Європейського суду по справі «Раманаускас проти Литви», у якому за обставинами справи заявник, який працював прокурором, повідомив, що через особистого знайомого до нього звернулась особа, яку він раніше не знав, і яка, насправді, була офіцером спеціального антикорупційного відділу поліції. Офіцер запропонував заявнику винагороду в розмірі 3000 доларів за обіцянку отримати виправдання третьої особи. Заявник спочатку відмовився, але згодом погодився, оскільки офіцер багаторазово повторював свою пропозицію. Офіцер повідомив своє керівництво, і пізніше заступник Генерального Прокурора дозволив йому імітувати злочинне діяння дачі цієї «винагороди». Незабаром заявник прийняв хабар від офіцера.

У серпні 2000 року його визнали винним у отриманні хабара у розмірі 2500 доларів і засудили до позбавлення волі. Вирок було залишено без змін апеляційним судом. Залишаючи без задоволення касаційну скаргу заявника, Верховний Суд зазначив, що не було доказів того, що перша розмова із заявником відбулась за вказівками поліції; що державні органи були повідомлені лише після того, як заявник погодився взяти хабар, і що, даючи дозвіл на наступні дії офіцера, вони лише долучались до злочинного діяння, яке вже вчинялось. Згідно з позицією Верховного Суду, питання провокації не мало наслідків для правової кваліфікації поведінки заявника.

Проте, розглянувши цю справу, Європейський суд вказав, що підбурювання з боку поліції має місце тоді, коли відповідні працівники правоохоронних органів або особи, які діють за їхніми вказівками, не обмежуються пасивним розслідуванням, а з метою встановлення злочину, тобто отримання доказів і відкриття кримінального провадження, впливають на суб'єкта, схиляючи його до вчинення злочину, який в іншому випадку не був би вчинений. Суд, щоб встановити, чи обмежилися офіцери лише «пасивним розслідуванням протиправної діяльності», повинен врахувати, що: у справі немає доказів, які б підтверджували, що заявник раніше вчиняв злочини, зокрема пов'язані з корупцією; як засвідчують записи телефонних розмов, заявник неодноразово зустрічався із офіцером з ініціативи останнього (цей 
факт, очевидно, спростовує наведені Урядом доводи про те, що правоохоронні органи жодного разу не тиснули на заявника і не вдавалися до погроз). Навпаки, через контакти, встановлені 3 ініціативи офіцерів, правоохоронні органи явно схиляли заявника до протиправних дій, хоча, крім чуток, не було об'єктивних доказів для припущення, що заявник займається незаконною діяльністю. Цих міркувань досить для обґрунтування висновку, що дії працівників правоохоронних органів вийшли за межі пасивного розслідування наявної протиправної діяльності. Оскільки доводи заявника не були повністю необґрунтованими, саме прокуратура мала довести, що факту підбурення не було. У разі відсутності таких доказів національні суди зобов'язані були проаналізувати факти у справі та вжити відповідних заходів, щоб встановити істину, а також з'ясувати, чи мало місце підбурювання [5]. Отже, мало місце порушення статті 6 Європейської конвенції.

Аналогічної думки дотримався Європейський суд під час розгляду справи «Тейшейра де Кастро проти Португалії», де заявника було засуджено за злочин у сфері обігу наркотичних засобів та їх аналогів, зазначивши, що суспільний інтерес не може виправдати використання доказів отриманих за допомогою провокацій поліції. При цьому Суд зробив висновок, що співробітники поліції не розслідували in an essentially passive manner (у суто пасивній манері) злочинну діяльність заявника, а здійснювали на нього такий вплив, щоб він вчинив злочин. Він установив, що їхні дії вийшли за межі функцій негласних агентів, оскільки вони спровокували злочин і не було підстав вважати, що його було б вчинено без їхнього втручання. Також Суд підкреслив, що в актах судових органів Португалії йдеться, що заявник був засуджений в основному на підставі показань двох поліцейських [6].

У справі «Таранекс проти Латвії» Суд вказав, що перший крок - з'ясувати, чи було б зазначене правопорушення вчинене без втручання влади. Визначення підбурювання, яке Суд дав раніше, передбачає, що підбурювання поліції відбувається тоді, коли відповідні працівники правоохоронних органів або особи, які діють за їхніми вказівками, не обмежуються лише розслідуванням злочинної діяльності за принципом пасивного характеру, але надають такий вплив на суб'єкта, що підбурює його до вчинення правопорушення, яке в іншому випадку не було б вчинене, а також для того, щоб зробити можливим доведення правопорушення, тобто забезпечити докази та порушити кримінальне переслідування. Вирішуючи, чи було розслідування «суто пасивним», Суд вивчає причини, що лежать в основі таємної операції та поведінку органів влади, що іiі проводять. Відтак, звертаючись до цієї справи, Суд наголошує, що всі телефонні дзвінки та приватні зустрічі, під час яких заявник нібито попросив агента виплатити хабар, як про це стверджував Урядовий уповноважений, відбулися за ініціативою або навіть наполяганням агента, а не заявника. Суд приділяє особливе значення події 18 грудня 2001 року, коли агент наполягав на очікуванні прибуття заявника, якого не було в офісі, а також відмовився отримати копію рішення від іншої особи та наполягав на обговоренні певних питань із заявником [7].

У справі «Люді проти Швейцарії» Європейський суд закріпив ще одну важливу умову. Він вказав, що хід розслідування справи не може здійснюватись лише за рішенням самого таємного агента. Докази можна було б вважати прямими, якби контроль за діями і рішеннями агента здійснювався безпосередньо його керівництвом чи слідчим суддею. Суд зазначив, що такі докази можуть ставити під сумнів хід усього розслідування. Також порушенням прав заявника стало те, що під час судового розгляду сторона захисту, подавши відповідне клопотання, була позбавлена можливості допитати агента як свідка у цьому кримінальному провадженні, оскільки як такий він залучений не був [8].

Рішенням у справі «Худобін проти Росії» Суд підкреслив, що необхідно встановлювати ясну і передбачувану процедуру щодо здійснення слідчих дій так само, як і спеціального контролю, щоб забезпечити доброчесність з боку органів державної влади та дотримання належних цілей з боку правоохоронних органів. У цій справі міліцейська операція була санкціонована простим адміністративним рішенням структурного підрозділу, який надалі проводив операцію. Як убачається 3 матеріалів справи, в тексті цього рішення містилося дуже мало інформації щодо причин і цілей запланованої «перевірочної закупівлі». Крім того, операція не перебувала під судовим контролем або будь-яким іншим незалежним контролем. За відсутності повної системи перевірки під час проведення операції роль більш пізнього контролю з боку суду першої інстанції стає вирішальною. Європейський суд зазначає, що в суді першої інстанції були допитані лише три свідка: Т., М. (товариш заявника, який був присутній під час його затримання) і мати заявника. Співробітники міліції, які проводили «перевірочну закупівлю», жодного разу не були допитані в суді, хоча сторона захисту просила, щоб їх допитали [9, п. 135].

Отже, Європейський суд вказує, що порушення права на справедливий суд наявне тоді, коли національні суди всіх інстанцій беруть до уваги ті докази, які були здобуті службовими особами проти винного під час проведення спеціального завдання, у рамках якого здійснювалась провокація злочину в активній манері. А саме порушення статті 6 Конвенції полягає у тому, що докази, які слід було б визнати недопустимими, стають плацдармом для пред'явлення обвинувачення, а відтак й винесення обвинувального вироку.

Цікавим $€$ рішення по справі «Мілінііне проти Литви", де Європейський суд остаточно визначив межі законних дій службової особи, які в подальшому унеможливлюють визнання доказів недопустимими під час проведення негласних слідчих (розшукових) дій. За обставинами справи заявниця, яка працювала суддею, хотіла продати свій автомобіль. Зустрівшись зі знайомим для обговорення деталей продажу, останній негласно записував розмову на диктофон. Пізніше ця ж особа подала скаргу в спеціальний антикорупційний підрозділ поліції, стверджуючи, що заявниця зажадала від нього хабар у вигляді нового автомобіля за винесення рішення у цивільній справі на його користь. Заступник генерального прокурора санкціонував застосування «моделі симуляції злочинної поведінки» на термін в один рік. У жовтні 1998 року заявниця була затримана в своєму кабінеті під час отримання іншого хабара від знайомого, а через 2 роки засуджена до позбавлення волі на 4 роки з позбавленням права обіймати посади публічної служби строком на 5 років. 
Відхиляючи її касаційну скаргу, Верховний Суд вказав, що попередня інформація про її готовність прийняти хабар підтверджена тим, що вона прийняла пропозицію без будь-якого зовнішнього тиску. Така пропозиція не може розглядатися як активне підбурювання до вчинення злочину. Більше того, Верховний Суд зазначив, що всупереч доводам заявниці поліцейські не могли припинити розслідування після отримання нею першого грошового внеску, оскільки для цілей кваліфікації її дій потрібно встановити, чи виконає вона свою обіцянку, вирішивши справу на користь позивача.

У цій справі ініціатива підбурювання до вчинення злочину належала приватній особі, а не представнику держави. Проте з урахуванням того, що ця особа мала поліцейську підтримку, роблячи заявниці пропозицію про виплату значної суми, і була забезпечена технічними засобами для запису їхньої розмови, можна зробити висновок, що поліція впливала на хід подій. Але Європейський суд не погодився з вимогами заявниці про те, що поліція допустила зловживання, з огляду на іï обов'язок перевіряти заяви про кримінальне правопорушення і важливість протидії впливу судової корупції на верховенство права в демократичному суспільстві. Вирішальним фактором $\epsilon$ не роль поліції, а поведінка вказаної особи і заявниці. Тому Європейський суд визнає, що в підсумку можна стверджувати, що поліція «приєдналася» до злочинної діяльності, а не ініціювала ii, тобто має місце пасивне підбурювання [10]. А отже правоохоронні органи в уособленні держави забезпечили спрямованість на запобігання, попередження злочинної діяльності, що без сумніву $є$ необхідним в демократичному суспільстві.

Висновки. Зважаючи на вищенаведене, можна сформулювати орієнтовні критерії належного здійснення оперативно-розшукової діяльності, а також проведення негласних слідчих (розшукових) дій, в межах яких здійснюється підбурювання до вчинення злочину, а також за якими не будуть наявні порушення прав людини і докази не будуть визнані недопустимими:

1) такі дії службової особи повинні бути передбачені чинним законодавством;

2) дії службової особи не повинні мати кримінально-караний характер. Тобто повинні бути запроваджені чіткі межі повноважень, в яких підбурювання до злочину буде вважатись законним (наприклад, за підбурювання до підкупу службову особу можна притягти до кримінальної відповідальності за статтею 370 Кримінального кодексу України);

3) повинні існувати механізми координації роботи службової особи під час проведення оперативно-розшукової діяльності або негласних слідчих розшукових дій, які включатимуть підбурювання до вчинення злочину, у вигляді судового контролю, тобто ухвали слідчого судді. Оскільки виконання спеціального завдання не може відбуватись за рішенням самого виконавця (слідчого, детектива) або його безпосереднього керівника;

4) повинна існувати спрямованість на запобігання, попередження злочинної діяльності, що без сумніву $\epsilon$ необхідним в демократичному суспільстві;

5) слідство загалом має проводитись in an essentially passive manner, як було вказано Європейським судом у рішенні «Тейшейра де Кастро проти
Португалії». Тобто слід виключити повторні пропозиції, тиск на особу, нав'язливі нагадування, умовляння, погрози і таке інше.

\section{Література}

1. Кримінальний процесуальний кодекс України : Закон України від 13 квітня 2012 року № 4651-VI. Верховна Рада України. URL: https://zakon.rada.gov.ua/laws/ show/4651-17.

2. Про оперативно-розшукову діяльність : Закон України від 18 лютого 1992 року № 2135-XII. Верховна Рада України. URL: http://zakon4.rada.gov.ua/laws/show/213512/conv/print1360050276201189.

3. Конституція України від 28 червня 1996 року № 254к/96-BP. Верховна Рада України. URL: http:// zakon4.rada.gov.ua/laws/show/254\%D0\%BA/96-\%D0\%B2\%D1\%80.

4. Про виконання рішень та застосування практики Європейського суду з прав людини : Закон України від 23 лютого 2006 року № 3477-IV. Верховна Рада України. URL: https://zakon.rada.gov.ua/laws/show/3477-15.

5. Judgment of European Court of Human in case of RAMANAUSKAS v. LITHUANIA (Application no. 74420/01) dated 05.02.2008. The HUDOC database. URL: https:// hudoc.echr.coe.int/eng\#\{\%22fulltext\%22:[\%22Ramanauskas\% 22],\%22documentcollectionid2\%22:[\%22GRANDCHAMBER\%22, $\% 22$ CHAMBER\%22],\%22itemid\%22:[\%22001-84935\%22]\}.

6. Judgment of European Court of Human in case of TEIXEIRA DE CASTRO v. PORTUGAL (Application no. 25829/94) dated 09.06.1998. The HUDOC database. URL: https:// hudoc.echr.coe.int/eng\#\{\%22fulltext $\% 22$ : [\%22\\%22CASE $\% 20$ OF\%20TEIXEIRA\%20DE\%20CASTRO\%20v.\%20PORTUGALI\%22\%22 ],\%22documentcollectionid2\%22:[\%22GRANDCHAMBER\%22,\%2 2CHAMBER\%22],\%22itemid\%22:[\%22001-58193\%22]\}.

7. Judgment of European Court of Human in case of TARANEKS v. LATVIA (Application no. 3082/06) dated 02.12.2014. The HUDOC database. URL: https:// hudoc.echr.coe.int/eng\#\{\%22fulltext\%22:[\%22\\%22CASE\%20 OF\%20TARANEKS\%20v.\%20LATVIAI\%22\%22],\%22documentcolle ctionid2\%22:[\%22GRANDCHAMBER\%22,\%22CHAMBER\%22],\%22i temid\%22:[\%22001-148268\%22]\}.

8. Judgment of European Court of Human in case of LÜDI v. SWITZERLAND (Application no 12433/86) dated 15.06.1992. The HUDOC database. URL: https:// hudoc.echr.coe.int/eng\#\{\%22fulltext\%22:[\%22Ludi\%22],\%22d ocumentcollectionid2\%22:[\%22GRANDCHAMBER\%22,\%22CHAM BER\%22],\%22itemid\%22:[\%22001-57784\%22]\}.

9. Judgment of European Court of Human Rights in case of KHUDOBIN v. RUSSIA (Application no 59696/00) dated 26.10.2006. The HUDOC database. URL: https:// hudoc.echr.coe.int/eng\#\{\%22fulltext\%22:[\%22KHUDOBIN\%22] ,\%22documentcollectionid2\%22:[\%22GRANDCHAMBER\%22,\%22 CHAMBER\%22],\%22itemid\%22:[\%22001-77692\%22]].

10. Judgment of European Court of Human Rights in case of MILINIENE v. LITHUANIA (Application no 74355/01) dated 24.06.2008. The HUDOC database. URL: https:// hudoc.echr.coe.int/eng\#\{\%22fulltext\%22:[\%22Milinien \%C4\%97\%20v.\%20Lithuania\%22],\%22documentcollectionid2 \%22:[\%22GRANDCHAMBER\%22,\%22CHAMBER\%22],\%22item id\%22:[\%22001-87142\%22]].

Шевченко Ю. А., студентка

Інституту прокуратури і кримінальної юстиції Національного юридичного університету імені Ярослава Мудрого 